\title{
Výchovné poradenství očima žáků základních škol
}

\author{
Petra Kalibová, Romana Zikmundová
}

\begin{abstract}
Abstrakt: Příspěvek Výchovné poradenství očima žáků základních škol prezentuje výsledky specifického výzkumu, který významně přispívá k orientaci v pohledu mladé generace na tuto disciplínu a konfrontuje je s možností uplatnění sociálního pedagoga v této oblasti. Cílem výzkumu bylo zmapovat pohled žáků 6. a 9. ročníků základních škol v České republice na poskytování výchovného poradenství ve školách. Výzkum byl realizován pomocí dotazníku na celkem 2585 respondentech a vyplývají z něho odpovědi na několik výzkumných oblastí, a to povědomí žáků o existenci výchovného poradenství, jejich zkušenosti s výchovným poradcem, osobnost výchovného poradce a spolupráce s rodiči nebo názory žáků na nahrazení výchovných poradců sociálními pedagogy.
\end{abstract}

Klíčová slova: sociální pedagogika, výchovné poradenství, základní škola, žák

\section{1 ÚVOD}

Výchovné poradenství je disciplínou, která signifikantně vstupuje do školského systému po celém světě. Problematika výchovného poradenství se objevuje v celé řadě odborných prací, zejména potom $v$ těch zahraničních. Zahraniční autoři se zabývají např. teoretickou základnou výchovného poradenství, hodnocením poradenstvíze strany studentů a žáků, různými pohledy n a roli výchovného poradce, nároky žáků a studentů, které kladou na osobnost výchovného poradce apod.

V České republice je výchovné poradenství často diskutovaný pojem, odborníci i laická společnost kritizují současný stav. Tento článek se nechal inspirovat celou řadou zahraničních výzkumů (Howieson, Semple, 2000, Fox, Butler, 2007, Boulton et al., 2007) a interpretuje výsledky realizovaného výzkumného šetření, které se zaměřuje na výchovné poradenství očima žáků základních škol. Může pomoci objevit pohled mladé generace na práci výchovných poradců ve školách a orientovat se $v$ něm.

\section{VÝCHOVNÉ PORADENSTVÍ A JEHO VZTAH K SOCIÁLNÍ PEDAGOGICE}

Výchovné poradenství prochází obdobím určitých změn, na roli výchovného poradenstvíve školstvíje kladen velký důraz, stejnějako na samotné výchovné poradce jsou kladeny stále vyššínároky. Školská poradenská oblast se dostává do popředí také díky zvyšujícím se tendencím $k$ integračním a inkluzivním aktivitám, kteréjsou v českém školství neméně aktuální otázkou. Výchovný poradce je tak styčná osoba pro práci s dítětem integrovaným do běžného typu školy (Wamocho, 2008). 0 této disciplíně se také zvyšuje společensképovědomí. Wyne a Skjei (1970) se zmiňujío tom, že v minulosti byl výchovný poradce chápán (především laickou veřejností) spíše jako současný asistent pedagoga. 
Společnost stále zvyšuje své nároky také na učitele, kterým nezbývá př́liš času na to zabývat se problémy svých žáků (Lam, Yuen, 2008). Lam a Yuen (2008) na druhou stranu uvádí, že pedagogové jsou sice ochotni zabývat se problémy svých žáků a začínají být více paidotropicky zaměřeni, i tak je ale nutné ve škole vytvořit pracovní pozici pro osobnost, která nebude zatižena prímou pedagogickou činností, ale bude připravena řešit se žáky osobní, výchovné i vzdělávací problémy, bude zastávat preventivní funkci školy atd.

Na našem území bývá systém výchovného poradenství kritizován především proto, že výchovný poradce bývá ve většině prípadủ učitel se sniženým počtem vyučovacích hodin, často nedobrovolně získávající tuto roli (srov. Vávrová, 1999). V zahraničníliteratuře se objevuje kritika nejasnosti v roli poradenského pracovníka (např. Whiston et al., 2009). Berry (1979) hovoří o několika základních nedostatcích výchovného poradenství ve světě. Jedná se přede vším o nedostatečnou teoretickou prípravu výchovných poradců (Fourie, 2007), nerespektování individuality a věkových specifik dětského klienta (McFarland et al., 2009).

Výchovný poradce je jakýsi „rodič ve školní třídě“, který zastává roli lékaře, právníka, soudce, administrativního pracovníka, učitele a intervenčního pracovníka (Agbaje, Eyo, 2011). Výchovný poradce je pedagog, který s žákem pracuje nejen ve třídě, ale také mimo ni (Usher, Edwards, 2005). Vzhledem knárůstu výskytu téměř všech forem rizikového chování u žáků základních škol a neustálému snižování věkové hranice prvního kontaktu s jednotlivými typy rizikového chování je role výchovného poradce a školního metodika prevence (př́padně školního psychologa) ve školním prostredí nezastupitelná.

Současná mladá generace je ve velké míre ovlivněna různými společenskými změnami, které se odrážejí v jejich soukromém životě. Mohou narušovat také školní život a bránit efektivnímu vzdělávání (Fox, Butler, 2007). Přitom právě školní prostředí je jedno z nejdůležitějších, kde by se mělo odehrávat preventivní působení, které předchází vzniku deviantního chování dětía mládeže. Vlivem stále častějších zkušeností dětí a mládeže s jednotlivými sociálními deviacemi je ve školách neoddiskutovatelně nutná př́tomnost pracovníka, který zahrne činnosti výchovného poradce, školního metodika prevence i škol ního psychologa (Anderson, Moore, 2009, Kraus, 2008). Často bývá výchovné poradenství a osobnost výchovného poradce také stavěna do souvislosti s otázkou diskutované sexuální výchovy (Usher, Edwards, 2005). I tato oblast by jistě mohla spadat do kompetencí sociálního pedagoga na školách.

O zkvalitnění poradenství usiluje sociální pedagogika, která se snaží o nahrazení školských poradenských pracovníků právě sociálním pedagogem, kterýje na tuto pozici velmi dobře připraven. Podle Lam a Yuen (2008) by taková nově vzniklá pozice školnímu prostředí velmi prospěla. Poradenský pracovník by tak nejen pomáhal žákům a studentům řešit aktuální problémy, ale pracoval by zejména dlouhodobě na rozvíjení schopnosti zvládání stresu a doprovázel by žáka na cestě vlastního návrhu řešení náročné nebo krizové životní situace. Výchovné poradenstvíje jakási príprava dítěte na život ve společnosti, výchovný poradce by měl být průvodce dítěte, kromě specificky zaměřené primární prevence by se měl také zabývat nespecifickým preventivním působením ( Niwaz et al., 2010). Žáci by tak měli znát své slabé a silné stránky, umět se vyrovnávat se stresovými situacemi, prvky asertivního jednání apod. Podle Opekarové $(2007,5)$ je důležité připravit poradenského pracovníka (at́ už to bude výchovný poradce, nebo sociální pedagog) na tuto pozici a nadále posilovat kooperaci jednotlivých subjektů poradenského procesu, primárně především s řediteli škol a dalšími pedagogy (Ward, 2010). Poradenský pracovník by měl mít „emocionální, sociální, odborné, výchovně-vzdělávací, zdravotnické, rozvíjející a organizační kompetence spojené se smyslem pro multikulturalitu a ochotu být lidem (a to jak intaktním, tak také těm se speciálními potřebami) nápomocný s řešením stresových situacís cílem co nejlépe zkvalitnit jejich život" (Agbaje, Eyo, 2011, 307). A právě tyto kompetence získávají v teoretické i praktické rovině studenti oboru sociální pedagogika na českých vysokých školách. 
Umístění sociálního pedagoga do českého školství by znamenalo obrovský posun ve výchovně vzdělávacím procesu. Sociální pedagog je odborně teoreticky i prakticky prripraven na práci vedukačním procesu a navíc by jeho zapojení do školství znamenalo odstranění všech výše zmíněných aktuálních problémů výchovného poradenství. Podle Krause (2008) sociální pedagog působí na klienty ve dvou rovinách, a to $v$ rovině integrační (tedy na místo výchovného poradce by prováděl depistáž ohrožených jedinců, prováděl by krizovou intervenci apod.) a v rovině rozvojové (preventivně působí na všechny žáky, vede je ke zdravému životnímu stylu atd.).

\section{POHLED ŽÁKŮ ZÁKLADNÍCH ŠKOL NA VÝCHOVNÉ PORADENSTVÍ}

Lašek $(2007,14)$ uvádí, že roli žáka dítě získává po vstupu do školy. Průcha (1997) chápe žáka jako subjekt edukace. Výchovný poradce pracuje nejen se žáky intaktními, ale také se žáky mimořádně nadanými či se žáky se speciálními vzdělávacími potřebami. Navázání vztahu mezi žákem a učitelem (potažmo výchovným poradcem) je dlouhodobé a stojí na vytvořeníformální a neformální autority (Petty, 1996). Žáci základních škol se potýkají během edukačního procesu s celou řadou stresujících podnětů, jako např. přestup z prvního na druhý stupeň Zš, psychické a fyzické změny v důsledku nástupu pubescence, rozhodování o budoucím životě volbou střední školy apod. Právě na žáky, kteří jsou těmito změnami ovlivněni, je zaměřeno výzkumné šetření kvantitativní povahy. Obdobný výzkum byl realizován v roce 2007 (Fox, Butler, 2007) ve Velké Británii a z jeho výsledků vyplynulo, že délka školní docházky dítěte ovlivňuje jeho povědomí o existenci výchovného poradce ve škole. Obecně podle autorů výzkumu platí, že povědomí žáků o existenci výchovného poradce ve škole je velmi nízká, což vyplývá i z názorů respondentů o nutnosti jakési „propagace“ výchovného poradenstvíve škole.

\subsection{Cíl výzkumu}

Cílem výzkumného šetřeníje zmapovat pohled na výchovné poradenství očima žáků základních škol a odpovědět na stanovené výzkumné otázky.

- Jaké je povědomí žáků o existenci výchovného poradce ve škole?

- Jaký by měl výchovný poradce podle respondentů být? (Kopřiva, 1997)

- Jaký je pohled žáků na volbu výchovného poradce ve škole? (Vávrová, 1999)

- Jaký je zájem rodičů o výchovné poradenství z pohledu respondentů?

- Jak podle respondentů přistupuje výchovný poradce k žákům? (Howieson, Semple, 2000)

- Jak důležitá je podle žáků funkce výchovného poradce ve škole? (Fox, Butler, 2007)

\subsection{Výzkumná metoda a výzkumný soubor}

Pro výzkumné účely byl sestaven dotazník vlastní konstrukce, který obsahuje 18 výroků zaměřených na pohled respondentů na výchovné poradce na školách. Každý výrok je doplněn postojovou škálou Likertovského typu od silného nesouhlasu po silný souhlas. Pro získání detailních informací jsme zvolili 2 variační (nezávislé) proměnné, které mohou sejmutím dotazníku získaná data ovlivnit: pohlavírespondenta a ročník, který žák absolvuje. Kompletnízněnídotazníku vč. instrukce je součástí prílohy. Dotazník byl distribuován mezi žáky 6. a 9. ročníků základních škol. Žáci šestého ročníku byli zvoleni z důvodu přechodu mezi prvním a druhým stupněm zš a fyzických i emocionálních změn $v$ důsledku nástupu puberty. Výsledky byly komparovány s žáky devátých ročníků základních škol, a to především z důvodu prípravy na přechod na střední školy (Kesici, 2007). 
Dotazník vyplnilo celkem 2585 respondentů z 58 základních škol. Výzkumný soubor byl konstruován na základě záměrného výběru. Zahrnuty byly školy ze všech krajů ČR a různé velikosti dle počtu žáků. Podrobnější informace o výzkumném souboru naznačují následující tabulky.

Tabulka 1

Výzkumný soubor dle pohlaví

\begin{tabular}{cc}
\hline Pohlaví & Počet respondentů \\
\hline Dívky & $\mathbf{1 2 9 2}$ \\
Chlapci & $\mathbf{1 2 9 3}$ \\
\hline
\end{tabular}

Tabulka 2

Výzkumný soubor dle věku

\begin{tabular}{cc}
\hline Ročník základní školy & Počet respondentů \\
\hline 6. & $\mathbf{1 3 3 8}$ \\
9. & $\mathbf{1 2 4 7}$ \\
\hline
\end{tabular}

\subsection{Interpretace výsledků}

Po vyhodnocení dotazníků byla zjištěna následující data, která pro přehlednost rozdělíme do několika oblastí tak, jak byla prezentována v dotazníku.

\section{Povědomío výchovném poradci ve škole}

Oblast Povědomí o výchovném poradci ve škole vychází z dotazníkových položek číslo 1, 2.

Povědomí o existenci výchovného poradce ve škole je frekventovaná položka dotazníků i v celé řadě zahraničních výzkumů a přináší opakovaně velmi neuspokojivé výsledky. Z našeho výzkumného šetření vyplynulo, že 1829 respondentů ví, kdo je výchovným poradcem ve škole. 124 nemá povědomí o tom, kdo je výchovný poradce ve škole. Celkem tedy $71 \%$ oslovených žáků zcela souhlasí nebo spíše souhlasís tím, že ví, kdo je ve škole výchovný poradce. Lze říci, že většina námi oslovených respondentů je o prítomnosti tohoto pracovníka ve škole dobře informovaná. Ve větší míre jsou o existenci výchovného poradce ve škole informováni žáci 9. ročníků, z hlediska pohlaví nebyly zjištěny signifikantní rozdíly. Vyšší povědomí o výchovném poradenst ví mezi žáky devátých ročníků připisujeme obecně zaběhlému schématu na poli českého výchovného poradenství, kdy se žáci s výchovným poradcem setkávají intenzivněji právě v rámci kariérového poradenství v posledním ročníku základní školy.

Dotazník se dále $v$ rámci této oblasti zaměřil na povědomí o možnostech osobního setkání s výchovnými poradci. Z šetření vyplývá, že $60 \%$ respondentů ví, na jakém místě a v jakém čase výchovného poradce může navštívit. Pouze $77 \%$ respondentů, kteří ví, kdo je výchovný porad ce, má také povědomío tom, kde a kdy může jeho služby využít. To znamená, že ačkoliv žáci mají povědomí o existenci výchovného poradce ve škole, ne každý z nich je seznámen s konzultačními hodinami nebo jinými možnostmi kontaktování poradce. $V$ praxi českého školství bývá zvykem, že výchovný poradce stanovuje tzv. konzultační hodiny, ve kterých je př́tomen pro osobní setkání se žáky nebo jejich zákonnými zástupci. Konzultačníhodiny bývajízveřejněny v prostorách školy, prípadně také na webových stránkách instituce. Vzhledem knárůstu využívání informačních a komunikačních technologií ve školství je možné se setkat i s modernizací služeb výchovných poradců na některých školách. Výchovní poradci na př́iklad nabízejí konzultační hodiny také on-line přes nejrůznější komunikační platformy (v současné době nejčastěji přes sociální sit' Facebook), kdy opět nabízí žákům potažmo rodičům dobu, ve kterou budou připraveni komunikovat přes chat. Tento způsob 
komunikace bývá v odborném kruhu pozitivně kvitován, jelikož může být takováto forma kontaktu s výchovným poradcem pro žáka velmi atraktivní.

\section{Zkušenostis výchovným poradcem}

Oblast Zkušenosti s výchovným poradcem vychází z položek dotazníku číslo 3 a 8.

Respondenti odpovídali také na otázky týkajíci se osobních zkušeností s výchovným poradcem ve škole. Z celkového počtu respondentů se na výchovného poradce obrátilo s dotazem nebo problémem pouze 236 žáků, což představuje $9 \%$ probandů. Jednalo se o 133 dívek a 103 chlapců, 90 ze šestých ročníků a 146 z ročníků devátých. Nejčastěji se na výchovného poradce obracejí dívky $z$ devátých ročníků.

Ze žáků, kteři se obrátili na výchovného poradce, se nejčastěji řešily problémy týkající se výběru střední školy (74), problémy s učením a specifické poruchy učení (17), šikana (21) a třídní a školní klima (nejčastěji potom vztahy mezi žáky a učiteli -34).

$28 \%$ (735) respondentů by se s osobním problémem na výchovného poradce nikdy neobrátilo, naopak s výrokem zcela nesouhlasilo $18 \%$ žáků. $Z$ tohoto můžeme usuzovat, že výchovný poradce si ve škole poměrně získává důvěru svých žáků. Co se týká pohlaví, jsou výsledky poměrně rovnocenné, nikdy by se na výchovného poradce neobrátilo 390 chlapců a 345 dívek.

Ze všech 735 žáků, kteří by se nikdy na výchovného poradce neobrátili, by se 496 žáků (67\%) na výchovného poradce s osobním problémem neobrátilo, protože mu př́liš nedůvěřují, není jim sympatický, mají obavy, že by sdělenou informaci neudržel v tajnosti, neznají ho na tolik, aby mu svěřili osobní problém, stydíse nebo jim nepřipadá vhodné se mu svěřovat. Zbylých 239 žáků (33\%) by se s problémem obrátilo na rodiče, prátele nebo jiné blízké osoby, případně by si problém vyřešili sami.

\section{Osobnost výchovného poradce}

Oblast Osobnost výchovného poradce je podložena položkami číslo 4, 5, 9, 10, 12, 13, 14, 15 a 16.

Celá řada dotazníkových položek se orientovala na problematiku osobnosti výchovného poradce a pohledu žáků na něho.

Pouze 47 \% respondentů vnímá, že se výchovný poradce chová k žákům přátelsky, nikoliv nadřazeně. Autorky príspěvku by očekávaly, že výchovný poradce jako poradenský pracovník bude vzbuzovat tolik potřebnou důvěru právě demokratickým př́stupem $\mathrm{k}$ žákům, nikoliv však nadřazeným.

Zajímavý pohled na výchovné poradenství přináší oblast volby výchovného poradce ze strany žáků. Z výsledků šetření totiž vyplývá, že pouze 45 \% žáků souhlasí s tím, aby si žáci zvolili výchovného poradce sami. Vzhledem $k$ tomu, že žáci často nemají k poradci dostatek dưvěry, očekávali bychom, že zájem o volbu výchovného poradce bude signifikantně vyšší.

54 \% oslovených respondentů vnímá, že výchovný poradce nemá na žáky dostatek času. Právě tento výsledek hovoří opět pro zavedení pozice sociálního pedagoga do škol.

Za pozitivní považujeme výsledky týkajícíse pozornosti výchovného poradce věnov ané žákům. Jedna z dotazníkových položek zjištóvala, zda výchovný poradce neupřednostňuje některou ze skupin žáků. 61 \% žáků odpovědělo, že se výchovný poradce ve škole věnuje všem žákům stejně a nedělá mezi nimi žádné rozdíly.

Velmi pozitivní je potom fakt, že celých 78 \% oslovených žáků považuje výchovné poradenství ve škole za důležité. Budeme-li komparovat pozitivní postoj žáků dle pohlaví a věku, jsou výsledky srovnatelné. Za důležité považuje výchovné poradenství $52 \%$ dívek a $48 \%$ chlapců a $51 \%$ žáků 
z 6. ročníku a $49 \%$ z 9. ročníku. Ačkoliv se tedy děti na výchovného poradce osobně neobracejí, chápou existenci poradenského pracovníka ve škole jako pozitivní.

Možnost obrátit se na výchovného poradce s osobním problémem či dotazem mimo konzultační hodiny je další mnohdy diskutovanou oblastí. Výchovní poradci v praxi nejčastěji nabízejí žákům konzultace $v$ předem stanoveném čase, avšak mimo tyto konzultační hodiny to již není možné. Pouze 39 \% účastníků šetření říká, že se mohou na výchovného poradce obrátit také mimo konzultační hodiny, a to na príklad prostřednictvím elektronické pošty, telefonu nebo sociálních sítí. Právě elektronická komunikace (pro mladou generaci především potom sociální sítě) představuje v současné době obrovský potenciál pro navázání kontaktu s potenciálními klienty výchovného poradce. Na některých školách již fungují také virtuální konzultační hodiny, $v$ rámci kterých je výchovný poradce on-line na vytvořeném profilu na sociální síti a může tak komunikovat se žákem, který by na příklad nenašel odvahu k osobnímu setkání. Stejně tak mohou tuto platformu využívat i rodiče, kteříse nemohou dostavit osobně do školy v předem vymezených konzultačních hodinách.

Velmi diskutovanou otázkou českého školství zůstává feminizace tohoto prostředí, která se promítá také do školního poradenství. Odborníci se stále zabývají tím, zda by poradenský pracovník měl být zastoupen ženským, nebo mužským pohlavím. Z realizovaného výzkumného šetření vyplynulo, že žáci základních škol preferujív roli výchovného poradce spíše ženu než muže. Výchovného poradce muže upřednostnilo pouze $13 \%$ respondentů, z toho signifikantně více chlapci než dívky.

Jedním ze znaků profesionálního poradenského pracovníka by měla být schopnost udržet tajemství. Pouze 57 \% respondentů našeho výzkumného šetření si myslí, že výchovný poradce dokáže udržet tajemství. Právě obavaz nedodržení svěřeného problému se stala nejčastějším důvodem, proč by se žáci výchovnému poradci nesvěřili. Důvěryhodnost by však měla být u poradenských pracovníků na prvním místě.

Velmi překvapivévýsledky přinesla položka týkajícíse výchovného poradce jako učitele. Problematika pedagogů, kteří se často proti své vůli a bez zájmu a motivace (případně dokonce bez adekvátního vzdělání) stávají poradenskými pracovníky, je stále palčivou oblastí. Kritizuje se nejen nedostatek času řadového pedagoga věnovat se plně této pozici, ale také vnímání této duální role žáky. Z výzkumného šetření vyplynulo, že každý druhý oslovený žák souhlasí s tím, že výchovný poradce by měl být někdo jiný než učitel, se kterým se žáci setkávají během vyučování. I toto můžeme chápat jako argument pro zavedení pracovních míst pro sociální pedagogy v českém školství.

\section{Výchovné poradenstvía rodiče žáků}

Výzkumné šetření se také zaměřilo na rodiče žáků a jejich kontakt s výchovnými poradci na českých základních školách. Tato oblast vychází z dotazníkových položek číslo 6,7 a 11 . Pouze $48 \%$ respondentů potvrdilo, že jejich rodiče ví, kdo zastává funkci výchovného poradce ve škole. Vzhledem k tomu, že škola (a výchovní poradci především) by měla být v úzké kooperaci se zákonnými zástupci dítěte, považujeme tento výsledek za alarmující. Jako nutné se jeví zvýšit informovanost rodičů o existenci poradenských pracovníků ve škole.

Následující dotazníková položka se zaměřila na to, zda rodiče žáků vůbec projevují zájem o to být informováni, kdo je ve škole výchovným poradcem. Z celkového počtu respondentů souhlasilo s výrokem pouhých $21 \%$ probandů. Lze tedy konstatovat, že zájem o výchovné poradenství ze strany zákonných zástupců žáků základních škol je velmi mizivý.

Na druhé straně ale žáci ze 61 \% potvrdili, že na výchovného poradce na jejich škole se rodiče mohou obrátit a vnímají tak tedy, že výchovní poradci jsou připraveni navazovat spolupráci s jejich zákonnými zástupci. Autorky články navrhují zvýšit povědomí zákonných zástupců o těchto pozicích ve škole napřiklad osobními schůzkami, zveřejněním výchovného poradce na webových stránkách školy apod. Zvýšení povědomíale podle našeho názoru začíná už u činností poradenských pracovníků 
- tedy je podstatné, aby se rodiče orientovali v tom, jaké konkrétní úkoly tito pracovníci provádějí a $v$ čem mohou být rodičům a jejich dětem prospěšní.

\section{Výchovný poradce z pohledu žáků}

Poslední oblast dotazníku si kladla za cíl odpovědět na otázky týkající se návrhů žáků na zlepšení výchovného poradenství ve škole a požadavků na výkon profese výchovného poradce z pohledu respondentů. Této oblasti odpovídají položky číslo 17 a 18.

Účastníci šetřeníměli možnost navrhnout až tři vlastnosti, schopnosti, nebo dovednosti, které by měl mít ideální výchovný poradce. Nejčastěji se vyskytovala odpověd’ hodný, milý a diskrétní. Další požadavky (včetně komparace názorů podle pohlaví) ukazuje následující graf.

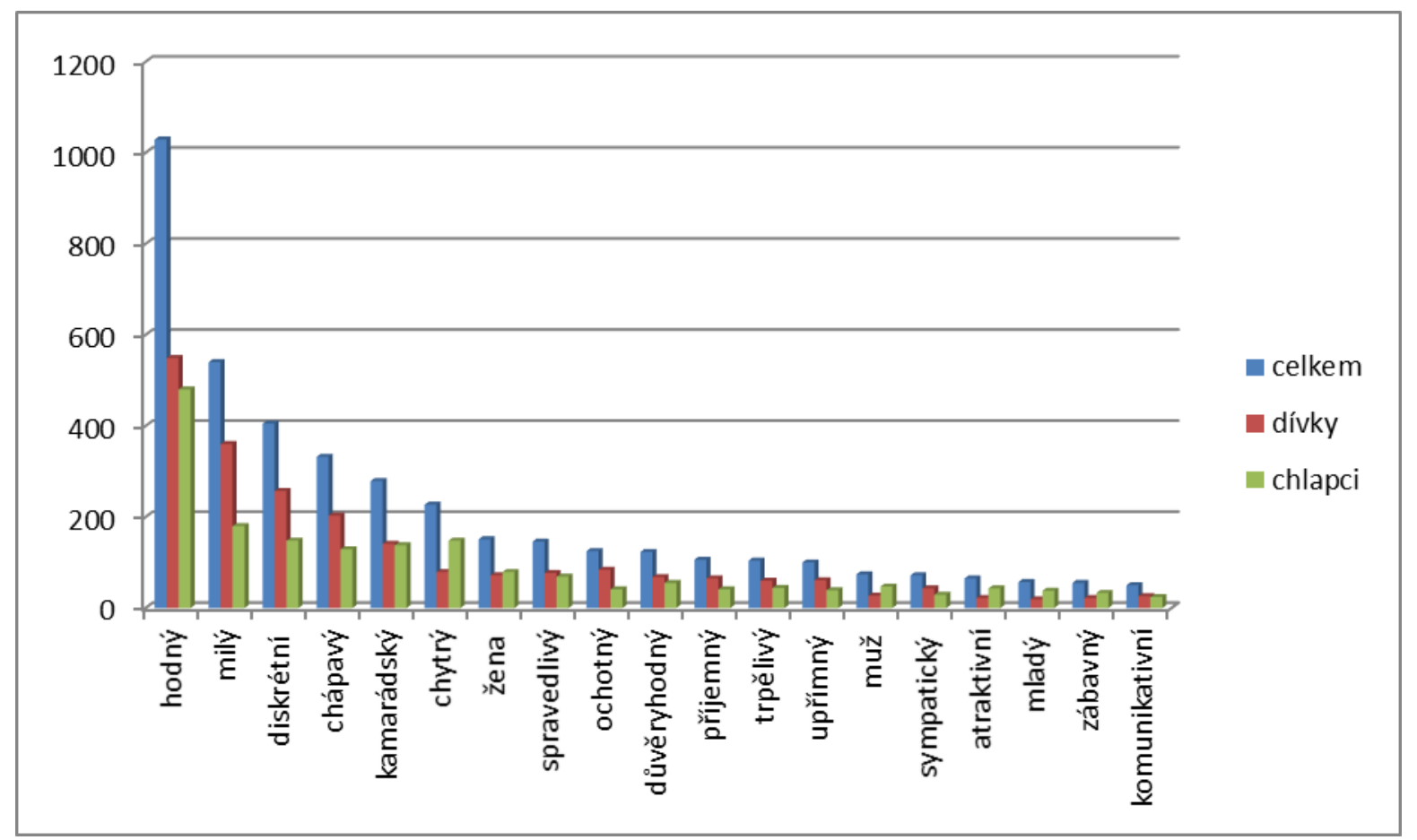

Obrázek 1. Požadavky na výkon profese výchovného poradce

Schopnosti, dovednosti, vlastnosti a další charakteristiky výchovného poradce očima žáků základních škol shrnuje názorně i následující obrázek vytvořený metodou Word Cloud. V obrázku jsou zvýrazněna ta slova, která se v odpovědích respondentů objevovala s nejvyšší četností. 


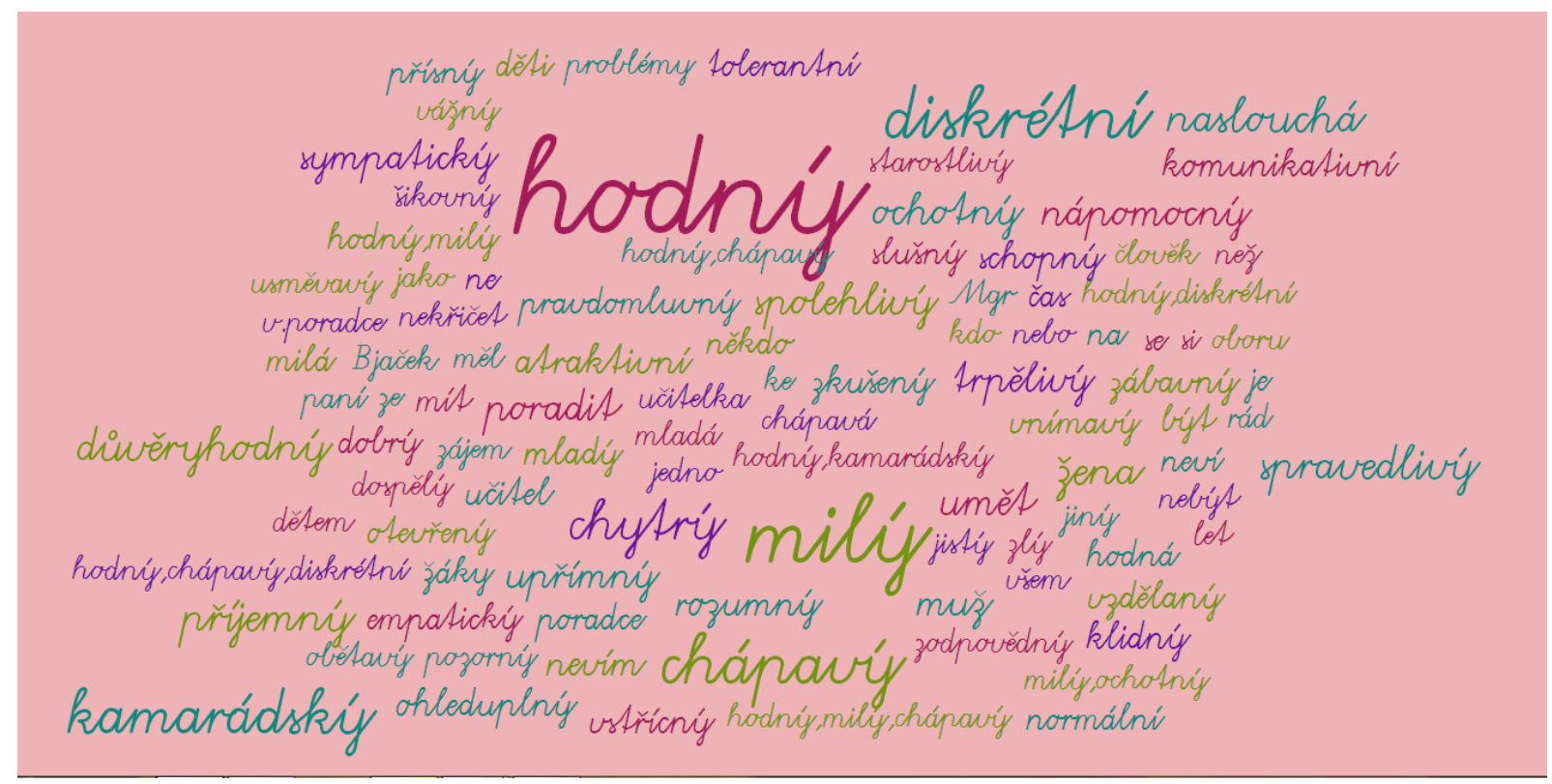

Obrázek 2. Požadavky na výkon výchovného poradce zobrazené metodou Word Cloud

Respondentiměli také možnost vyjádřit se $k$ návrhům na zlepšení výchovného poradenství na dané škole. Nejčastěji se objevil návrh na zlepšení dostupnosti výchovného poradce pro žáky a zvýšení povědomí žáků o existenci tohoto pracovníka ve škole, dále potom změna výchovného poradce za „nepedagoga“ a zvýšení časové dotace na poradenství pro žáky. Další výsledky ukazuje následující graf.

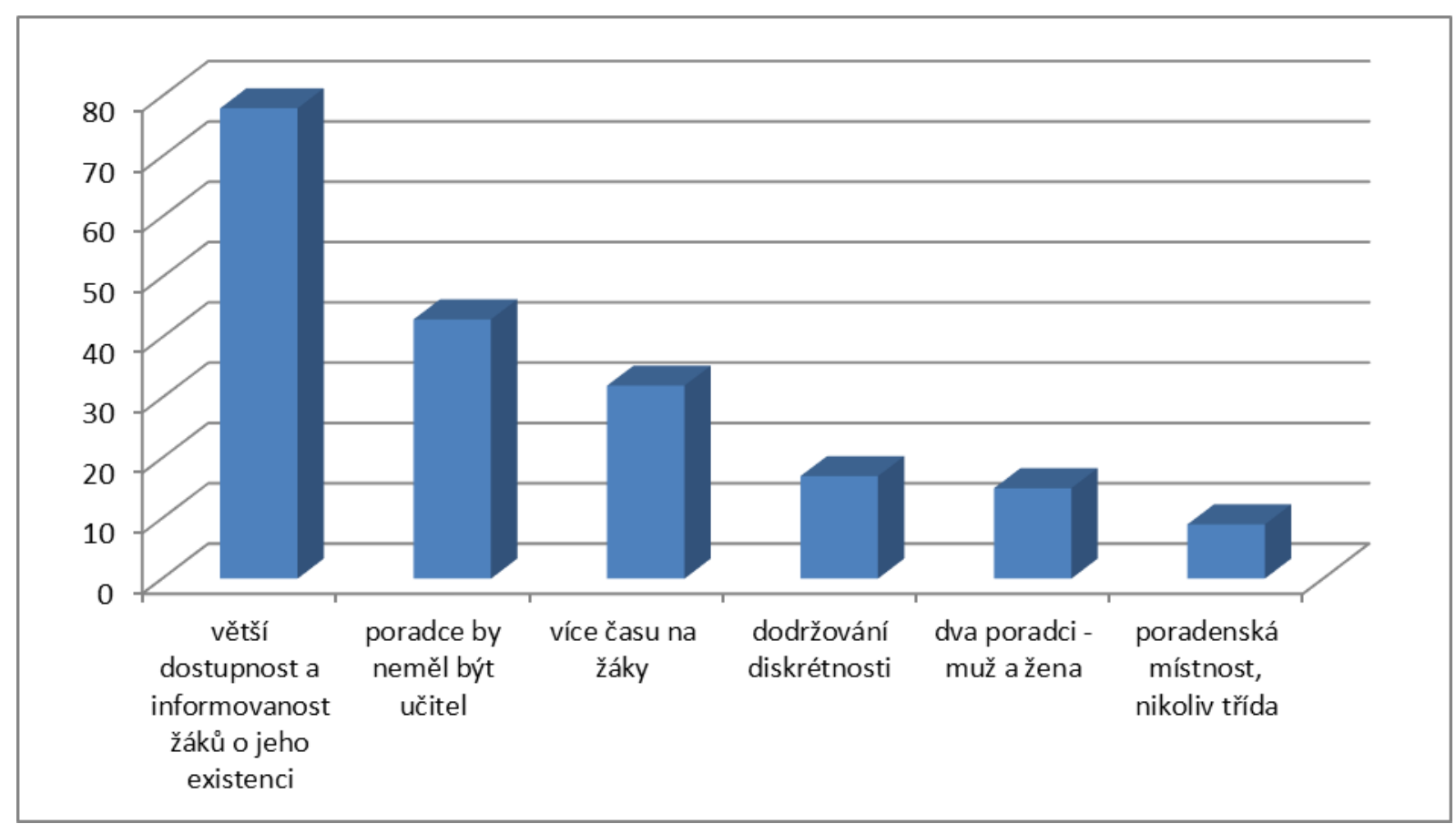

Obrázek 3. Prostor pro zlepšení výchovného poradenství

Z odpovědírespondentů v poslední oblasti výzkumného šetřeníjasně vyplývá, jaké vlastnosti jsou pro děti z jejich pohledu u poradenského pracovníka důležité. Nedostatkyvýchovného poradenství, které vyvstaly z odpovědí probandů, se týkají dostupnosti a informovanosti žáků o existenci a činnostech výchovného poradce, dále potom žáci preferují poradce, který nebude učitelem, bude mít na žáky vyšši časovou dotaci, poradenské činnosti by měly být realizovány ve speciální místnosti pro ně 
určené (nikoliv ve školní třídě nebo kanceláři před dalšími pedagogy). Žáci negativně vnímají častou neschopnost výchovného poradce udržet svěřené tajemství a navrhují zlepšit poradenskou oblast také zavedením dvou poradenských pracovníků -ženy a muže.

\section{ZÁVĚR}

Výchovné poradenství je dosud poměrně málo probádanou oblastí, která je však velmi podstatnou součástí soudobého školství a je možné $v$ rámci ní nalézt celou řadu styčných bodů se sociální pedagogikou. V době, kdy se $v$ České republice stále častěji hovoří o slovenském sociálně pedagogickém vzoru, vyvstává otázka nahrazení poradenských pracovníků ve škole právě osobností sociálního pedagoga. Vzhledem k proměnám současné postmoderní společnosti je role tohoto pracovníka ve školním prostředí nezastupitelná. Sociální pedagog ve škole by tak mohl zastávat roli poradce, průvodce, mentora, kouče, animátora, lektora primární prevence, kariérního poradce apod. Potřeba takového pracovníka ve školství je v současnosti o to aktuálnější, že rodiče často funkce, které by měli zastávat oni sami, vlivem změn v moderních rodinách přesouvají na jiné instituce a očekávají tedy, že jednotlivé instituce připraví dítě na život ve společnosti.

Vzhledem k tomu, že má sociál ní pedagog veškeré předpoklady pro tyto činnosti a nebyl by zatížen prímou pedagogickou činností, je pravděpodobné, že by vznikl prostor pro zlepšeníkooperace škol se zákonnými zástupci žáků a dalšími institucemi a odborníky.

Z realizovaného výzkumného šetření vyplynulo, že sami žáci považují výchovné poradenství za důležitou součást školy, ale je z jejich pohledu nutné odstranit nedostatky, které brání tomu, aby se na výchovného poradce obraceli (a to jak sami žáci, tak také jejich rodiče). Pokud shrneme výsledky výzkumu, je možné říci, že poptávka po profesionálovi, který bude teoreticky i prakticky připraven stát se oporou pro děti a mládež v nelehké době dospívání v současné společnosti, je vysoká, a to nejen ze strany odborníků např́č obory, ale i z pohledu samotných žáků.

Vzhledem k tomu, že je prozatím role sociálního pedagoga v tuzemsku nejistá, je téma této studie aktuální interdisciplinární problematikou a bude třeba se jí zabývat z různých úhlů pohledu i v následujících letech.

\section{LITERATURA}

AGBAJE, A. A., \& EYO, U. E. (2011). Counselling Psychologists'Skills, Educational Reforms and Innovations in Nigeria Primary Schools. International Journal of Academic Research, 3(5), 307316.

ANDERSON, S. W., \& MOORE, P. A. (2009). The Impact of Education and School-Based Counseling on Children's and Adolescents'Viewf of Substance Abuse. Journal of Child and Adolescent Substance Abuse, 18, 16-23.

BERRY, E. (1979). Guidance and Counseling in elementary school:Its Theoretical Base. Personnel and Guidance Journal.

BOULTON, M. J. et al. (2007). Secondary school pupils'views of their school peer counseling for bullying service. Counselling and Psychotheraphy Research, 7(3), 188-195.

FOURIE, J. A. (2007). Educational and vocational guidance and information services for the youth in public libraries. South African Journal of Library and Information Science, 73(1), 51-63.

FOX, C. L., \& BUTLER, I. (2007). If you don't want to tell anyone else you can tell her: young people's views on school counselling. British Journal of Guidance and Counselling, 35(1), 97-114.

HOWIESON, C., \& SEMPLE, S. (2000). The evaluation of guidance:listening to pupils'views. Brittish Journal of Guidance and Counselling , 28(3), 373-388. 
KESICl, S. (2007). Middle School Students'Guidance and Counseling Needs. Educational Sciences: Theory and Practise, 7(3), 1325-1349.

KOPŘIVA, K. (1997). Lidský vztah jako součást profese. Praha: Portál.

KRAUS, B. (2008). Základy sociální pedagogiky. Praha: Portál.

LAM, C., \& YUEN, M. (2008). Applying solution-focused questions with primary school pupils: A Hong Kong tecaher's reflections. Pastoral Care in Education, 26(2), 103-110.

LAŠEK, J. (2007). Sociálně psychologické klima školních tříd a školy. Hradec Králové: Gaudeamus.

MCFARLAND, L. et al. (2009). Reflective Practice and Self-Evaluation in Learning Postive Guidance: Experiences of Early Childhood Practicum Students. Early Childhood Education Journal, 36, 505-511.

NIWAZ, A. et al. (2010). An Analysis of Guidance Services for Secondary School Students in Pakistan. Academic Research, 2(5), 389-393.

OPEKAROVÁ, O. (2007). Kapitoly z výchovného poradenství. Praha: UJAK.

PETTY, G. (1996). Modernívyučování. Praha: Portál.

PRŮCHA, J. (1997). Moderní pedagogika. Praha: Portál.

USHER, R., \& EDWARDS, R. G. (2005). Subjects, networks and positions: Thinking educational guidance differently. British Journal of Guidance and Counselling , 33(3), 397-410.

VÁVROVÁ, P. (1999). Učitel jako poradce. Hradec Králové: Gaudeamus.

WAMOCHO, F. I. et al. (2008). Development of the guidance programme with special educational needs in Kenya:a study on personal orientation. British Journal of Special Education, 35(4), 221229.

WARD, S. et al. (2010). School Counseling and School Educational Leader Preparations Programs: Partnerships in Training Skills in Open Communication. National Social Science Journal, 151156.

WYNE, M. D., \& SKJEI, P. (1970). The counselor and exceptional pupils: a critical review. Personnel and Guidance Journal, 48(10), 828- 835.

\section{PŘílOHA A - Dotazník}

Hezký den,

prosíme vás o vyplnění jednoduchého dotazníku pro žáky 2. stupně Zš, který se zabývá výchovným poradenstvím na školách. U každého výroku zakroužkujte, do jaké míry s danou větou souhlasíte. Uněkterých otázek bude potřeba doplnit konkrétní odpověd'. Prosím, odpovězte na všechny položené otázky, a to co nejpravdivěji. Na vašich názorech nám záleží. Dotazník je anonymní, výsledky budou sloužit pouze pro účely Univerzity Hradec Králové. Nezapomeňtevyplnit také pohlaví a ročník.

Děkujeme za spolupráci, moc jste nám pomohli.

Pohlaví: žena muž

Ročník:

\section{Vím, kdo je výchovný poradce v naší škole.}

Zcela souhlasím Spiše souhlasím Nejsem sijistý/á Spiše nesouhlasím Zcela nesouhlasím 
2. Vím, kde výchovného poradce najdu a kdy za ním mohu přijít.

Zcela souhlasím Spíše souhlasím Nejsem sijistý/á Spišenesouhlasím Zcela nesouhlasím

3. Obrátil/a jsem se již na výchovného poradce s nějakým dotazem, problémem.

Zcela souhlasím Spiše souhlasím Nejsem sijistý/á Spiše nesouhlasím Zcela nesouhlasím Jednalo se o:

4. Výchovný poradce se $k$ žákům naší školy chová jako kamarád.

Zcela souhlasím Spiše souhlasím Nejsem sijistý/á Spišenesouhlasím Zcela nesouhlasím

5. Výchovného poradce by si měli zvolit sami žáci.

Zcela souhlasím Spišesouhlasím Nejsem sijistý/á Spišenesouhlasím Zcela nesouhlasím

6. Moji rodiče vědí, kdo ve škole zastává funkci výchovného poradce.

Zcela souhlasím Spišesouhlasím Nejsemsijistý/á Spišenesouhlasím Zcela nesouhlasím

7. Moji rodiče se zajímají o to, kdo je výchovný poradce.

Zcela souhlasím Spiše souhlasím Nejsem sijistý/á Spišenesouhlasím Zcela nesouhlasím

8. Na výchovného poradce bych se s osobním problémem neobrátil/a.

Zcela souhlasím Spišesouhlasím Nejsemsijistý/á Spišenesouhlasím Zcela nesouhlasím Na výchovného poradce bych se s osobním problémem neobrátil/a, protože

9. Výchovný poradce na naší škole nemá na žáky dostatek času.

Zcela souhlasím Spiše souhlasím Nejsem sijistý/á Spiše nesouhlasím Zcela nesouhla sím 10. Výchovný poradce se věnuje všem žákům stejně, nedělá mezi nimi žádné rozdíly.

Zcela souhlasím Spiše souhlasím Nejsem sijistý/á Spišenesouhlasím Zcela nesouhlasím

11. Na výchovného poradce na naší škole se mohou obrátit i rodiče.

Zcela souhlasím Spišesouhlasím Nejsem sijistý/á Spišenesouhlasím Zcela nesouhlasím

12. Mít ve škole výchovného poradce je důležité.

Zcela souhlasím Spiše souhlasím Nejsem sijistý/á Spišenesouhlasím Zcela nesouhlasím

13. Na výchovného poradce se mohu obrátit také mimo školu (např. přes e-mail, Facebook, telefon)

Zcela souhlasím Spiše souhlasím Nejsem sijistý/á Spišenesouhlasím Zcela nesouhlasím

14. Výchovný poradce by měl být muž.

Zcela souhlasím Spiše souhlasím Nejsem sijistý/á Spiše nesouhlasím Zcela nesouhlasím

15. Výchovný poradce na naší škole dokáže udržet tajemství. 


\title{
Zcela souhlasím Spiše souhlasím Nejsem sijistý/á Spišenesouhlasím Zcela nesouhlasím
}

16. Výchovný poradce by měl být někdo jiný než učitel, se kterým se setkáváme během vyučování.

Zcela souhlasím Spiše souhlasím Nejsem sijistý/á Spišenesouhlasím Zcela nesouhlasím

\section{Výchovný poradce by měl být:}

a)

b)

c)

18. Na výchovném poradenství na naší škole bych zlepšil/a:

a)

b)

c)

\section{Autor}

Mgr. et Mgr. Petra Kalibová, Univerzita Hradec Králové, Pedagogická fakulta, Rokitanského 62, 50003 Hradec Králové, e-mail: petra.kalibova@uhk.cz

Bc. Romana Zikmundová, Univerzita Hradec Králové, Pedagogická fakulta, Rokitanského 62, 50003 Hradec Králové, e-mail: romana.zikmundova@uhk.cz

Článek je publikován v rámci projektu Specifického výzkumu z roku 2013.

\section{Educational counseling from the perspective of primary school pupils}

\begin{abstract}
The study, Educational Counseling from the Perspective of Primary Schools Pupils' presents the results of specific research which contributes significantly to the orientation in the attitudes and opinions of the young generation towards this discipline, and confronts them with the possibility of becoming social educationalists in this area. The aim of the research was to explore the attitudes, opinions and experiences of pupils in the 6th and 9th grades at primary schools in the Czech Republic regardng the provision of educational counseling in schools. The research was conducted using a questionnaire given to a total of 2,585 respondents and the results cover several research areas - pupils' awareness of the existence of educational counseling, their experience with the school counselor, the personality of the educational consultant and his/her co-operation with the parents, or the pupils' opinions on replacing educational consultants with social educators.
\end{abstract}

Keywords: educational counseling, pupil, primary school, social education 